\title{
Increased urinary excretion of thioether in new rubber workers
}

\author{
I KILPIKARI' AND H SAVOLAINEN² \\ From the Department of Occupational Health, ' Oy Nokia Ab, Rubber Industries, Nokia, and Department of \\ Industrial Hygiene and Toxicology, ${ }^{2}$ Institute of Occupational Health, Helsinki 29, Finland
}

ABSTRACT Urinary excretion of thioether before starting work and in the early work period in a rubber factory was measured in urine samples collected after one, two to four, and five or more months of starting work. The study population consisted of 84 new workers. The urinary excretion of thioether decreased after one month's exposure and increased thereafter up to five months. Measurement of urinary thioethers in groups of new workers is therefore informative of exposure to alkylating agents only after several months from starting work. This effect may be mediated by the induction of the pertinent metabolic pathway.

Exposure to electrophilic compounds can be detected in industry by measuring urinary thioether excretion. ${ }^{1-3}$ In practice, the most important value of urinary thioether measurement appears to be its signal function regardless of the routes of the exposure to electrophilic compounds. ${ }^{1}$ Urinary excretion of thioether has been shown to be increased in several industries. ${ }^{24}$.

Previous reports, ${ }^{235}$ have shown that the urinary excretion of thioethers reflects exposure in the rubber industry. The purpose of this study was to evaluate further the excretion of thioethers among new rubber workers before starting work and after one, two to four, and five or more months from the start.

\section{Subjects and methods}

The population under study consisted of 84 new workers in a tyre factory. Freshly voided urine samples were collected before starting work and during work. The samples were collected at the end of an eight-hour working day on Thursday or Friday and stored at $-25^{\circ} \mathrm{C}$ until analysis.

\section{EXPOSURE}

Processes undertaken in the tyre factory include mixing and milling, calendering, component preparation and assembling, curing, and finishing. Exposure in the mixing and milling department is mainly to dust and the mode of exposure is through the lungs. In calendering and curing there is exposure to fumes originating from hot rubber. The mode

Received 12 November 1981 Accepted 18 January 1982 of exposure is again through the lungs. In component preparation and assembling the exposure originates from rubber bulk handled manually and the mode of exposure is through the skin.

\section{ANALYSIS OF URINARY THIOETHERS}

Urinary thioethers were determined after an alkaline hydrolysis as described by Vainio $e t \mathrm{al}^{2}$ and expressed as $\mu \mathrm{mol}$ of urinary thioether per mmol of creatinine in order to adjust for differences in the concentration of urine.

\section{Results}

Altogether 177 urinary thioether measurements were carried out, 84 before working and 93 during work. The mean urinary excretion of thioether was $79 \pm 4$ (expressed as $\mu \mathrm{mol} / \mathrm{mmol}$ creatinine $\pm \mathrm{SE}$ of mean) before work. After one month's work the urinary excretion of thioether decreased to $60 \pm 5$ and during the second to fourth months the excretion increased to $81 \pm 5$; after the fifth month or later the excretion reached $95 \pm 6$ (table 1 ).

The excretion of urinary thioethers in different

Table 1 Mean urinary excretion of thioether by group basis before work and after one, two to four, and over five months' exposure. Values are expressed as $\mu \mathrm{mol} / \mathrm{mmol}$ creatinine $\pm S E$

\begin{tabular}{lllll}
\hline \multicolumn{5}{l}{ No of months } \\
\cline { 2 - 5 } & 0 & 1 & $2-4$ & $\geqslant 5$ \\
\hline Mean & $79 \pm 4$ & $60 \pm 5$ & $81 \pm 5$ & $95 \pm 6$ \\
No & 84 & 32 & 35 & 26 \\
\hline
\end{tabular}


Table 2 Mean urinary excretion of thioether before work and after one, two to four, and over five months' exposure. Values are expressed as $\mu \mathrm{mol} / \mathrm{mmol}$ creatinine $\pm S E$. (Number of subjects in parentheses)

\begin{tabular}{|c|c|c|c|c|}
\hline \multirow[t]{2}{*}{ Department } & \multicolumn{4}{|l|}{ Months } \\
\hline & 0 & 1 & $2-4$ & $\geqslant 5$ \\
\hline $\begin{array}{l}\text { Mixing and milling } \\
\text { Component preparation } \\
\text { and assembling }\end{array}$ & $\begin{array}{l}86 \cdot 0 \pm 6 \cdot 3(24) \\
74 \cdot 8 \pm 5 \cdot 1(41)\end{array}$ & $\begin{array}{l}44^{*} \pm 5 \cdot 6(13) \\
71 \cdot 3 \pm 9 \cdot 2(11)\end{array}$ & $\begin{array}{l}72.9 \pm 12(9) \\
75 \cdot 0 \pm 6.6(19)\end{array}$ & $\begin{aligned} 108 & \pm 10.7(7) \\
87.4 & \pm 8.6(13)\end{aligned}$ \\
\hline Calendering and curing & $88 \pm 8 \cdot 3(16)$ & $72 \cdot 0 \pm 9 \cdot 0(8)$ & $94 \pm 10(6)$ & $94 \pm 7.0(3)$ \\
\hline
\end{tabular}

categories of workers decreased after one month's exposure, increased during the second to fourth month, and after five months or more reached a level higher than before the current work (table 2). The highest initial decrease was detected among the mixing and milling workers $(42 \mu \mathrm{mol} / \mathrm{mmol}$ creatinine).

Follow-up of eight individuals yielded the same results as those found in the cross-sectional study (table 3).

Table 3 Mean urinary excretion of thioether of eight individuals followed up for five months. Values are expressed as umol/mmol creatinine $\pm S E$.

\begin{tabular}{llll}
\hline & \multicolumn{3}{l}{ No of months } \\
\cline { 2 - 4 } & 0 & $1-4$ & 5 \\
\hline Mean & $86 \pm 11$ & $73 \pm 6$ & $118 \pm 10$ \\
\hline
\end{tabular}

\section{Discussion}

The glutathione S-transferase system is one of the pathways concerned in the neutralisation of reactive intermediates formed by the mixed function oxidases in the process that aims at removing absorbed lipophilic foreign chemicals. ${ }^{1}$ The intermediates may be epoxides or free radicals with a high chemical reactivity. Conjugation with a suitable nucleophilic acceptor such as glutathione renders them biologically less harmful. In the process a covalent bond from the glutathione sulphydryl to the reactive electrophilic centre is formed. The resultant compound is chemically a thioether. Thus the measurement of the concentration of formed thioethers provides an indirect index of exposure to potentially alkylating agents and of activity of glutathione S-transferase. Measurements of urinary excretion of thioether in new workers, however, seem to give pertinent results of occupational exposure only after five or more months.

Several inhibitors of insect glutathione
S-transferases are known. ${ }^{6}$ The present data suggest that an unidentified class of rubber chemicals may appreciably inhibit the human enzyme, and this could explain the reduced excretion of conjugation products during early exposure better than, for example, a hypothetical consumption of glutathione pool. Glutathione is virtually absent in human plasma, and the intracellular pool seems to be rapidly restored in healthy subjects. ${ }^{7}$ At least three glutathione S-transferase isoenzymes have been isolated in rat and mouse liver and in the housefly with molecular weights of 43000,44600 , and 53000 daltons without species-dependent differences. ${ }^{8}$ It is currently held that the transferase activity may be induced by prolonged exposure to agents with oxidative metabolism although it is not known which isoenzyme type is concerned as they show overlapping substrate specificity. 9

The proximate inducers do not need to be highly specific compounds-for example, antioxidant deficiency in rat yields increased transferase activity. ${ }^{10}$ Thus the increase in the urinary excretion of thioether in the new rubber workers might reflect enzyme induction rather than the accumulation of reactive chemicals during the early period of current occupation. This renders the urinary thioether determination unreliable as an index of exposure to the alkylating rubber chemicals in new workers.

The greatest decrease in urinary excretion of thioether was seen in mixing and milling workers, whereas their excretion was also the highest after five months. In component preparation and assembly departments as well as in calendering and curing the decrease was smaller than in mixing and milling, and they did not increase to the same level. The results seem to show that a high exposure causes a strong depletion in the enzyme activity, and that the enzyme induction is stronger than in a lower exposure. Measurement of the urinary excretion of thioether in order to estimate exposure at work should be started only after five to six months' exposure so that the error caused by the initial decrease in the urinary concentration of thioether may be eliminated. 


\section{References}

' Doorn van R, Leijdekkers CH, Bos RP, Brouns RME, Henderson PTH. Detection of human exposure to electrophilic compounds by assay of thioether detection products in urine. Ann Occup Hyg 1981;24:77-92.

${ }^{2}$ Vainio H, Savolainen H, Kilpikari I. Urinary thioether of employees of a chemical plant. Br J Ind Med 1978;35:232-4.

${ }^{3}$ Kilpikari I. Correlation of urinary thioethers with chemical exposure in a rubber plant. $\mathrm{Br} J$ Ind $\mathrm{Med} 1981 ; 38: 98-100$.

4 Seutter-Berlage F, van Dorp HL, Kosse HGI, Henderson PTH. Urinary mercapturic acid excretion as a biological parameter of exposure to alkylating agents. Int Arch Occup Environ Health 1977;39:41-51.

${ }^{5}$ Savolainen H, Vainio H, Kilpikari I. Urinary thioether determination as a biological exposure test. Acta Pharmacol Toxicol 1977;41(suppl IV):33.

- Kulkarni AP, Motoyama N, Dauterman WC, Hodgson E. Inhibition of housefly glutathione S-transferase by catecholamines and quinones. Bull Environ Contam Toxicol 1978;20:227-32.

'Wendel A, Cikryt P. The level and half-life of glutathione in human plasma. FEBS Lett 1980;120:209-11.

Motoyama N, Dauterman WC. Comparative studies on the molecular weight of glutathione S-transferases from mammalian livers and an insect. Comp Biochem Physiol (B) 1979;63:451-4.

${ }^{9}$ Lawrence RA, Baker PR, Cuschieri A. Separation of glutathione S-transferases by affinity chromatography. Biochem Soc Trans 1978;6:762-5.

- Stone WL, Dratz EA. Increased glutathione S-transferase activity in antioxidant-deficient rats. Biochim Biophys Acta 1980;631:503-6.

\section{The August 1982 issue}

\section{THE AUGUST 1982 ISSUE CONTAINS THE FOLLOWING PAPERS.}

Cancer mortality in the British rubber industry $\mathrm{H} \mathrm{G}$ PARKES, C A VEYS, J A H WATERHOUSE, AND ANN PETERS

Occupational exposure and 12-year spirometric changes among Paris area workers F KAUFFMANN, D DROUET, J LELLOUCH, AND D BRILLE

Evaluation of respiratory effects in miners and millers exposed to talc free of asbestos and silica $\mathrm{D} \mathrm{H}$ WEGMAN, J M PETERS, MARYANNE G BOUNDY, AND T J SMITH

Respiratory illness caused by overheating of polyvinyl chloride BRIGITTE FRONEBERG, L JOHNSON, AND P J LANDRIGAN

On the defensive action of glutamate against the cytotoxicty and fibrogenicity of quartz dust $\mathrm{K} I$ MOROSOVA, G V ARONOVA, B A KATSNELSON, B T VELICH KOVSKI, A M GENKIN, L N ELNICHNYKH, AND L I PRIVALOVA

Role of infective, immunological, and chronic irrative factors in the development of silicosis $G$ CHIAPPINO AND E C VIGLIANI

Theoretical basis of alveolar sampling G R KELMAN

Are coalminers, with low "risk factors" for ischaemic heart disease at greater risk of developing progressive massive fibrosis? A L COCHRANE, F MOORE, AND C B MONCRIEFF

Lung cancer mortality among residents living near the El Paso smelter W N ROM, GLORIA VARLEY, J L LYON, AND SARA SHOPKOW
Further follow-up study of workers from an asbestos cement factory H F THOMAS, I T BENJAMIN, P C ELWOOD, AND P M SWEETNAM

Ethnic differences in certified sickness absence $\mathrm{C} \mathrm{C}$ BAKER AND S J POCOCK

Occupational lead exposure of storage battery workers in Korea B $\mathrm{K}$ LEE

An increase in $\mathrm{Na}^{+} / \mathrm{K}^{+}-\mathrm{ATPase}$ activity of erythrocyte membranes in workers employed in a lead refining factory I KARAI, $K$ FUKUMOTO, AND $S$ HORIGUCHI

Effect of lead in vitro on water metabolism and osmotic fragility of human erythrocytes I KARAI, K FUKUMOTO, K KAGEYAMA, AND S HORIGUCHI

Thermocamera studies of gases and vapours $P$ CARLSSON, B LJUNGQVIST, AND K NEIKTER

Progression of vinyl chloride induced hepatic fibrosis to angiosarcoma of the liver D B JONES AND P M SMITH

Sodium azide poisoning in five laboratory technicians O P EDMONDS AND M S BOURNE

\section{Information section}

Notice

Correction:

Acute and subacute symptoms among workers in the printing industry (February 1982 p. 7075)

Copies are still available and may be obtained from the PUBLISHING MANAGER, BRITISH MEDICAL ASSOCIATION, TAVISTOCK SQUARE, LONDON WC1H 9JR, price $£ 4.25$ (USA $\$ 9.20$ ), including postage 